\title{
ELEKTROMOBILITÁS AZ ÁRUSZÁLLÍTÁSBAN
}

\author{
Orosz Tamás \\ BSc hallgató, Miskolci Egyetem \\ Logisztikai Intézet \\ 3515 Miskolc, Miskolc-Egyetemváros, email: orosz.tamas96@gmail.com \\ Veres Péter \\ egyetemi tanársegéd, Miskolci Egyetem \\ Logisztikai Intézet \\ 3515 Miskolc, Miskolc-Egyetemváros, email: altveres@uni-miskolc.hu

\section{Bányainé Tóth Ágota} \\ egyetemi docens, Miskolci Egyetem \\ Logisztikai Intézet \\ 3515 Miskolc, Miskolc-Egyetemváros, email: altagota@uni-miskolc.hu
}

\begin{abstract}
Absztrakt
Közeleg az elektromobilitás. Az autóipar komoly lépéseket tesz az elektromobilitás irányába, mely egyaránt érzékelhetö a fejlesztésben és a gyártásban. Az elektromobilitás képviseli napjaink egyik technológiai kihívását és lehetőségét. Ezek a változások mind a mikromobilitás, mind a makromobilitás területén éreztetik hatásukat. A mikromobilitás területén az elektromos kerékpárok és rollerek, míg a makromobilitás területén az elektromos személyautók és kamionok lesznek a potenciálisan rendelkezésre álló eröforrások. Jelen kutatómunka keretében azt vizsgáljuk, hogy az elektromos kamionok milyen gazdasági perspektívát jelenthetnek a közúti áruszállitásban.
\end{abstract}

Kulcsszavak: e-mobilitás, e-kamion, töltöállomás, gazdasági elemzés, környezeti szempontok

\begin{abstract}
E-mobility is coming. The automotive industry has launched a large e-offensive, which includes not only research but also manufacturing processes. The rise of e-mobility represents one of the most important technological changes. These changes will have a great impact on our life through microand macro-mobility. Micro-mobility will be represented by e-bikes, e-scooters or segway, while macro-mobility will be based on e-cars and e-trucks. Within the frame of our research work we analyse the financial impact of e-trucks.
\end{abstract}

Keywords: e-mobility, e-truck, charger stations, financial analysis, ecological impact

\section{Bevezetés}

Az elektromos hajtású járművek az elmúlt évtizedben egyre nagyobb visszhangot kaptak. Ez több dolognak is köszönhetö, mint például a globális felmelegedés, vagy a kőolaj készletek belátható időn belüli eltünése. Azonban a szakértők nem csak ezen tényezők hatására kezdtek el foglalkozni a témával. Az elektromos hajtású gépjármü gondolata gyakorlatilag egyidős a benzinmotoros autóéval. Az első ilyen gépjármúvet az angol Thomas Parker fejlesztette ki a 19. század végén. Kezdetben még csak az elektromos személyszállításban gondolkodtak a gyártó cégek, mára azonban már az 
áruszállításban is egyre nagyobb hangsúlyt fektetnek a hibrid illetve a teljesen elektromos hajtású haszon gépjárművekre is, kezdve a kis áruszállítóktól az E-kamionokig [1].

$\mathrm{Az}$ elektromos autó/kamion (villanyautó) egy villanymotorral meghajtott gépjármü, mely az elektromos energiát leggyakrabban egy, illetve akár több akkumulátorból nyeri. Egyes elektromos járművek azonban szuperkondenzátorokban tárulják az energiát. Beszélhetünk továbbá olyan autókról, melyek nem teljes mértékben elektromos hajtásúak, ezeket nevezzük hibrid autóknak. A hibrid jármüveket nem tekintjük teljes mértékben elektromos autóknak, mivel ezek csak töltéstároló üzemmódban müködnek. A hibridautó olyan jármü, amely a meghajtásához szükséges energiát több, egymástól eltérő elven müködő erőforrásból nyeri.

Az elektromos kamionok különös jelentőséggel bírnak mind költséghatékonyság, mind környezeti hatások szempontjából a negyedik ipari forradalom során kialakuló komplex kiberfizikai rendszerekben, ahol a megnövekedett és egyre inkább diverzifikálódott vásárlói igények kielégítése egyre hatékonyabb, ugyanakkor egyre kisebb emisszióval járó szállítási megoldásokat igényel, mint ahogy azt a Miskolci Egyetem Logisztikai Intézetének kutatási területei is alátámasztják [2-4].

Jelen kutatómunka témája a még gyerekcipőben járó elektromos kamionok jövője. Ugyan még egyik gyártó sem jelent meg a piacon elektromos kamionnal, azonban a tesztelések már elkezdődtek és néhány paramétert, jellemzőt már publikáltak is. Az elektromos autózásban élen járó Tesla nem csak a személyszállításban szeretné letenni a névjegyét, hanem a teherfuvarozásban is. Tanulmányunkban a Tesla Semi nevü modellt fogjuk elemezni és egyes paramétereit számítás révén megbecsülni. A legfőbb paraméterek elsősorban költségek lesznek, mint a kilométerenkénti futásköltség, szervizköltség, a vontató ára, üzemanyag költség, és a megbízhatóság. Témaválasztásunkat az indokolja, hogy az anyagmozgatás jövője ebben rejlik. Köztudott tény, hogy a Föld kőolajtartalékai belátható időn belül elfogynak, így a gyártóknak más alternatívát kell keresniük mind a személy, mind pedig a teherszállításra egyaránt. Az elektromos autózás sok előnnyel jár ${ }_{2}$ azonban egyik legnagyobb hátránya a tapasztalatlanságból fakadó megbízhatóság hiánya. Az elektromos autózás történelme már több mint száz évre nyúlik vissza, azonban a hétköznapokban való elterjedése még csak most fog kiteljesedni. A gyártók rengeteg pénzt fektetnek a $\mathrm{K}+\mathrm{F}$ tevékenységbe, azonban a közeljövőben még rengeteg elöre nem látható hibát kell majd a mérnököknek megoldani.

\section{Az elektromos kamionok jelene}

Az Európai Unió megfogalmazott egy célkitüzést, mely szerint átlagosan 30\%-kal kevesebb széndioxidot kell kibocsátaniuk az újonnan forgalomba kerülő nehézgépjármüveknek 2030-ra a 2019-es adatokhoz képest. A világ legnagyobb gazdasággal rendelkező országai (Kína, Egyesült Államok, Kanada, Japán) már mind megállapodtak egy limitben a $\mathrm{CO}_{2}$ kibocsátással kapcsolatban, azonban Európában ez az első ilyen törekvés. Ez azért is meglepö, mert a közlekedési szektorból származó légszennyezés közel negyede az áruszállításhoz köthető, holott a tehergépjárművek az összes jármü mindössze 5\%-át teszik ki az utakon. A javaslatot még el kell fogadnia a Parlamentnek és a tagállamok kormányainak, ám amikor ez megtörténik, a teherautókra vonatkozó új szabályozás hatalmas előnyhöz juttatja majd azon autógyártókat, melyek már elkezdtek elektromos, vagy valamilyen alternatív meghajtású kamiont gyártani, mint például a Volvo és a Daimler. De nem csak a gyártók kerülnek lépéskényszerbe; minden kamionflottát üzemeltető vállalatnak komolyan el kell gondolkodnia az elektromos átálláson.

A teherszállítási szektorban egyre gyakrabban tapasztalható feszültség a dízel, illetve az elektromos meghajtás párti vélemények között. Napjainkban egyelöre még kijelenthető, hogy nincs az 
elvárásoknak megfelelő kapacitású akkumulátor, amely kellően megbízható is lenne. Tehát egyelöre még nem biztosított a nagy távolságú szállítás ebben az üzemeltetési formában. Manapság egy átlagos tehergépjármü 200 kilométeres távolságot tud megtenni egy töltéssel, mely a mai logisztikai elvárások mellett egyértelmüen kijelenthető, hogy nem elegendő. A kétkedők leggyakrabban azt szokták hangoztatni, hogy a kamionoknál hatványozottan fontosabb a töltéshez szükséges idő hossza és a hatótáv. A soföröknek gyakran szoros határidővel kell leszállítaniuk a termékeket, amibe nem fér bele a 200 kilométerenkénti újratöltés $60-120$ percen keresztül, de a jelenlegi akkumulátor-technológia nem teszi lehetővé, hogy egy kamion ennél (sokkal) nagyobb távolságot megtegyen töltőberendezésre való csatlakozás nélkül. Azonban a villanymeghajtású kamionok jelentős mértékben hozzájárulnának a légszennyezés csökkentéséhez. A közepes és nehéz tehergépjárművekből származó üvegházhatású gázok emissziója 1990 és 2016 között 85\%-kal növekedett az Egyesült Államokban, a szállítmányozásból származó szénkibocsátás pedig 23\%-os részesedést tudhatott magáénak 2016-ban az Environmental Protection Agency adatai szerint. Az egyelőre nem világos, hogy az ipar készen álle a váltásra. Azonban azt kijelenthetjük, hogy a váltás be fog következni, a kérdés ezzel kapcsolatban csak az, hogy mikor lesz kész a technológia. Nem szabad elfelejteni viszont, hogy a kamiongyártók és minden kereskedelmi flotta üzemeltetőjének kezeit köti a környezetvédelmi szabályozás, márpedig az egyre szigorúbb elöírásoknak lehetetlen lesz megfelelni a létező legszennyezőbb meghajtással. Az elektromos kamionokra van igény, ezt a Tesla Semi már bizonyította: egymás után tették le a foglalót azon cégek, melyek hajlandóak voltak felnyitni a szemüket az egyetlen járható út felé. Kis hatótávú villanykamionokból, melyek városi feladatokra készültek, már most akad választék bőven, és ezek csendességével és tisztaságával semmilyen hagyományos jármü nem szállhat szembe. A nagyobb távolságú szállítás tekintetében pedig egyelöre még várnunk kell, hogy mit hoz a jövő.

Egy idén februárban megjelent cikk szerint a Nikola Motor Company is elkezdett gondolkodni az 100\%-ban elektromos hajtású haszongépjármüvekben (Nikola Tre, illetve a Nikola Two). Ez azért is meglepő, mivel a cég eddig a hidrogén meghajtású áruszállítás mellett érvelt és több ízben is kritizálták a Teslat, most azonban ök is előálltak két modellel. Ezeket a modelleket 500, 750, valamint 1000 kWh-s akkupakkal is lehet majd kérni. A mérnökök számítása szerint az $1 \mathrm{MWh}-\mathrm{s}$ akkumulátor pakkal felszerelt jármü akár a 640 km-es távolságot is sikeresen tudná teljesíteni, ez nagy előrelépést jelent az eddigi nagyjából 200 km-hez képest. Azonban hozzáteszik, hogy leginkább csak olyan város környéki feladatokra lesz alkalmas, ahol nem lapul túl nagy árutömeg a csomagtérben [5-7].

A Tesla Semi a világ első teljesen elektromos meghajtású nyerges vontatója. Erről először 2017 tavaszán tett említést Elon Musk. Gyártásának megindítását pedig az idei évre jósolták, azonban prototípusokat már 2018-ban is lehetett látni a közutakon közlekedni, tehát a tesztüzem már javában zajlik a bejelentés óta. A vállalat alapvetően azt helyezte kilátásba a modellel kapcsolatban, hogy teljes feltöltéssel akár 500 mérföld megtételére lesz képes, amely nagyjából 805 km-t jelent. Továbbá körülbelül 80\%-os töltöttség mellett 400 mérföld $(640 \mathrm{~km})$ megtételére lesz képes. Ha a Tesla által kifejlesztett úgynevezett Super Charger-t veszik igénybe a nyerges vontató feltöltéséhez, akkor ez feltehetően 30 percbe fog telni. Ezek a töltőállomások minél több napenergiát felhasználva töltik a jármüveket. Ezzel szintén a környezettudatosságot erösítik, mivel megújuló energiát használnak a jármü üzemeltetéséhez. Előzetes tervek szerint a Tesla automata pilóta szoftverével is fel lesznek szerelve a jármüvek, amely a gyorsforgalmi utakon teszi lehetővé a teljesen önálló vezetést. A teherautót négy villanymotor hajtja, melyek megegyeznek a Tesla Model 3-as motorjaival. A jármü 5 másodperc alatt gyorsul 100 kilométeres óránkénti sebességre vontatmány nélkül, ez a maximális vontatható tömeggel körülbelül 20 másodpercre nő. Akkumulátorai a vezetöülés alatt találhatók. Hátrányai közé tartozik, hogy a teherautóban mindössze egy soför számára van ülés, mivel az 
akkumulátorok helyigénye ennyit tett lehetővé. A vezető ülése nem a fülke egyik oldalán, hanem középen helyezkedik el. Több kamerával és szenzorral lesz felszerelve, mint a személyautók, ezáltal még biztonságosabbá próbálják tenni az automata pilótát. Képes lesz a sávkövetésre, vészfékezésre, valamint ha bármilyen veszély jelentkezik a jármü körül, azt azonnal jelzi a két érintőpanel valamelyikén a számítógép a soför számára [5-7].

A Tesla azt állítja, hogy a Semi $20 \%$-kal kevesebbe fog kerülni mérföldenként az üzemeltetőnek a dízeles társaival szemben, ami 1,51 dollár helyett csupán csak 1,26 dollárt jelent. Mindezek mellett még bejelentették az úgynevezett konvoj technológiát, mely még tovább csökkenti a költségeket.

A Tesla Semi referenciái már sokkal biztatóbbak, mint az eddig megjelent és előrevetített konkurenciáinak a nyerges vontatói. Logisztikai szempontból nagyon fontos, hogy ne csak a kis hatótávú közlekedésre legyenek alkalmasak, hanem akár a több száz kilométeres utakat is meg tudják tenni egy feltöltéssel a lehető legnagyobb megbízhatóság mellett. A mérnökök szerint ez teljesíthető a tesztüzemek során tapasztaltak alapján [8].

\section{Elektromos autó vs. belső égésü motoros személyautó}

Dízel vagy elektromos autó? Ahhoz, hogy ezt a kérdést megválaszoljuk, a motorháztető alá kell néznünk! Ha kicsit utána olvasunk, észrevesszük, hogy manapság erre a kérdésre egyértelmű választ igen nehéz adni, de véleménye bizonyára mindenkinek van a témával kapcsolatban, akit foglalkoztat. Ha szeretnénk kijelenteni, hogy melyik típus a jobb, először el kell döntenünk, hogy számunkra egy autó vásárlásakor melyek a legfontosabb szempontok.

Ha az üzemanyag-hatékonyságról, a zajszennyezésről és a levegőminőségről beszélünk, akkor az elektromos jármúvek egyértelmúen a nyertesek. Ha a forgatónyomatékról vagy kezdeti árról beszélünk, akkor a dízel motoros autók a jobbak. Itt azonban meg kell jegyezni, hogy az elektromos jármüvek egyes összetevői negatív hatást fejthetnek ki a környezetre az összeszerelés és a leszerelés során: különösen az akkumulátorok.

Egy elektromos autó valóban hatékonyabb? Ez egy bonyolult kérdés, amit nem egyszerü megválaszolni. Bár sokan azt állítják, hogy az elektromos jármüvek nem hatékonyabbak, mint a belső égésủ motorok, figyelembe kell vennünk, hogy ezek a források enyhén elfogultak.

Az Egyesült Államok Energiaügyi Minisztériumának Energiahatékonysági és Megújuló Energia Hivatala szerint ,az elektromos áramforrások a villamosenergia mintegy 59-62\% -át konvertálják a hálózatról a kerekekre. A hagyományos benzinmotorok a benzinben tárolt energia körülbelül 17-21\% -át konvertálják a kerekekre." De itt a dízelmotorokról beszélünk, melyek a benzinmotorok hatékonyságát legalább kétszeresen is felülmúlják.

Az elektromos jármúvek akkumulátoraiban szállított és tárolt villamosenergiából becslések szerint a gépjármü elektromos motorja 85-90\% -át veszi ki hatékonyan. Más szóval, ez az a mennyiség, amelyet a gép hasznos munkájához használ.

Minden bizonnyal sok emberben felmerül a kérdés, hogy vajon milyen energiából származik az erőművekben megtermelt energia? A villamos hálózaton szállított villamosenergia nagy hányadára igaz, hogy fosszilis tüzelőanyagból termelik az áramot az erőmüvekben.

Azonban figyelembe kell venni, hogy a dízel belsőégésű motoroknál az olajat meg kell találni, ki kell termelni, finomítani és szállítani kell az üzemanyag töltóállomásokra és nem csak úgy átszivattyúzzák. Ez többé-kevésbé hasonlít a fosszilis tüzelőanyagoknak az erőmüvek számára történő villamosenergia-termeléshez való szállításával. 
De mivel az egyes országok energia összetétele egyre több megújuló és alacsony kibocsátású forrást (nukleáris, szél, napenergia stb.) használ így, a dízel és az elektromos jármü közötti szakadék ezen a téren egyre jobban nő [9].

\section{Tesla Semi paramétereinek meghatározása számítások, illetve egy hasonló típusú, de dízel üzemú kamion alapján}

A Tesla Semi típusú modellje egy körülbelül 24 tonna teherbírású gépjármű lesz. Ezért egy ugyan ilyen teherbírású, de dízel üzemelésủ kamionnal fogjuk összehasonlítani, és az aránypárokkal meghatározni az értékeket. A főbb szempontok a következők lesznek: vontató ára, adó, üzemanyagköltség, biztosítás, szerviz költség.

Kezdjük tehát a vontató árával, a Tesla az 500 mérföld $(\sim 800 \mathrm{~km})$ hatótávú vontatóját 53.000.000 Ft-ért fogja árulni, legalábbis ezt vetítette elöre. Ez a 24 tonna teherbírású vontatójuk, míg egy ugyan ilyen csak dízel üzemü vontató körülbelül 25.000.000 Ft és 35.000.000 Ft körül mozog. Tehát nagyjából fele annyiba kerül, mint egy Tesla Semi.

Az adókat egyelőre nehéz megjósolni, mivel ez régiónként és országonként eltérő lehet. Azonban egyre valószínübb, hogy mint az EV-k esetében, úgy az elektromos kamionok esetében is jelentős adókedvezmény várható. Ez több dolognak lesz köszönhető. Egyrészt a zéró emissziónak, így a környezetvédelmi adó alól mentesülnek ezek a jármüvek, valamint az országok bizonyára motiválni szeretnék majd a fuvarozási vállalatokat, hogy térjenek át ilyen típusú jármúvekre, így akár az útdíjakat, útadókat is csökkenthetik.

Az üzemanyagköltség jelentheti a legnagyobb különbséget, a befektetés gyorsabb megtérülésének az esélyét. Itt ugyanis hatalmas különbségek tapasztalhatóak. Targoncák esetében ez a különbség 7,5szeres, míg az elektromos autók tekintetében ez 4-szeres, valamint a kanadai tanulmány szerint ez 4,6szoros. A három átlaga 5,4-szeres különbséget ad ki, de véleményünk szerint ez a különbség elérheti akár a 6-szoros arányt is. Egy átlag 24 tonna teherbírású Euro 6 besorolású DAF kamion 25,8 litert fogyaszt 100 kilométerenként, ami üzemanyagártól függően körülbelül 400 Ft Magyarországon. Tehát ez 10.320 Ft-ot jelent minden megtett 100 kilométer esetén, ami így az aránypárokkal átszámítva egy Tesla Semi kamion esetében körülbelül 1910 Ft körül fog alakulni. Ez lehet a megtérülés, illetve a hosszú távú befektetés megértésének kulcsa.

Egy másik mutató, mely tekintetében azonban az elektromos jármü alulmarad a dízelhez képest az a biztosítási összeg. Ez több dolognak is tudható be, mint például a kisebb vásárlói kör, valamint, hogy a technológia még nagyon gyerekcipőben jár, így magasabb a biztosítás költsége. Egy elektromos autó biztosításának az ára körülbelül 1,25-szerese egy dízel autóhoz képest. Egy online biztosításkötő felületen egy átlagos dízel kamion éves biztosítása 100.000 Ft-körül mozog, így 125.000 Ft-ra becsülhetjük az elektromos kamionokét. Ez az arány bizonyára megmarad a kamionok esetében is, azonban ez nem annyival magasabb, hogy ne térülhetne meg a befektetés. Egy másik kérdés az áru biztosítása, de erről sajnos nehéz megbízható adatot találni, mivel nagyon változatos és egyedi szerződésekről van szó.

Amiről még ez idáig csak alig esett szó, mint kalkulálandó költség, az az útdíj. Minden országnak meg van a saját stratégiája a nehézgépjármüvek és teherszállítójármüvek úthasználati díjának kalkulálására. Hazánkban a HUGO rendszer müködik, melynek minden adatot meg kell adni a jármüről és az útvonalról. Egy ekkora jármünek hazánkban a kilométerenkénti költsége jelenleg $100 \mathrm{Ft}$ körül mozog. Más országokban ez nagyon eltérő és komplikált lehet, így jelenlegi számításunkba csak 
a magyarországi utazást vesszük figyelembe. Mivel még nem tudjuk, hogy ha megjelennek, az elektromos kamionok kapnak-e kedvezményt, így ezzel az összeggel fogunk kalkulálni.

Korábban már említettük, hogy egy elektromotor hajtotta jármüben sokkal kevesebb olyan alkatrész van, mely elkophat, eltörhet, vagy rendszeres cserére szorulna. Ez a szerviz költségekre is kihatással van, mivel így semmilyen speciális szervizelési szakképzettséget nem igényel. A kevesebb alkatrész egyben azt is jelenti, hogy kevesebb olyan része van a vontatónak, ami elromolhat. Egy dízel üzemelésű vontatóra nagyjából $60.000 \mathrm{Ft} /$ hó szervizköltséget kell számolni, ami elég magas. Egy elektromos targonca átlagosan 2.900.000 Ft volt 5 évre, míg a dízel $5.800 .000 \mathrm{Ft}$, tehát kétszerese. Az elektromos autónál ez az arány a dízel üzemühöz képest $60 \%$ volt. Tehát, ha ezeket az adatokat vesszük alapul, akkor ez azt jelenti, hogy egy E-kamion esetében ez körülbelül $30.000 \mathrm{Ft} / \mathrm{hó}$ körül alakulhat a jövőben. Az alábbi táblázatokban látható a fent említett költségek összehasonlítása:

1. táblázat Saját számitások költségekre lebontva

\begin{tabular}{|l|r|r|r|r|r|r|}
\cline { 2 - 8 } \multicolumn{1}{c|}{} & \multicolumn{2}{c|}{$\begin{array}{c}\text { Vételi ár } \\
\text { (millió } \mathrm{Ft})\end{array}$} & $\begin{array}{c}\text { Tesla } \\
\text { számítása }\end{array}$ & \multicolumn{4}{c|}{ Saját számítások } \\
\cline { 3 - 8 } & & $\begin{array}{c}\text { Ráfordítás } \\
(\mathrm{Ft} / \mathrm{km})\end{array}$ & $\begin{array}{c}\text { Fogyasztás } \\
(\mathrm{Ft} / 100 \mathrm{~km})\end{array}$ & $\begin{array}{c}\text { Karbantartás } \\
\text { (Ft/hó) }\end{array}$ & $\begin{array}{c}\text { Útdíj } \\
\text { (Ft/km) }\end{array}$ & $\begin{array}{c}\text { Biztosítás } \\
\text { (Ft/év) }\end{array}$ \\
\hline Elektromos kamion (Tesla Semi) & 53 & 226 & 1910 & 35000 & 100 & 100000 \\
\hline Átlagos Dízel kamion & 30 & 272 & 10320 & 60000 & 100 & 125000 \\
\hline
\end{tabular}

2. táblázat 150000 km éves futásteljesitmény mellett a költségek alakulása

\begin{tabular}{|l|c|c|c|c|c|c|c|}
\hline \multirow{2}{*}{$150000 \mathrm{~km}$ éves futásteljesítmény melett (millió Ft) } & \multicolumn{4}{|c|}{ Saját számítások } \\
\hline \multirow{2}{*}{} & \multirow{2}{*}{ Vételi ár } & Tesla számítása & \multicolumn{4}{|c|}{} \\
\cline { 3 - 8 } & & Ráfordítás & Fogyasztás & Karbantartás & Útdíj & Biztositás & Összesen \\
\hline Elektromos kamion (Tesla Semi) & 53,00 & 33,90 & 2,87 & 0,42 & 15,00 & 0,10 & 18,39 \\
\hline Átlagos Dízel kamion & 30,00 & 40,80 & 15,48 & 0,72 & 15,00 & 0,13 & 31,33 \\
\hline
\end{tabular}

Számításaink alapján a fenti táblázatból látható, hogy az eltérés a kamionokra szükséges ráfordítások esetében körülbelül másfélszeres, míg a Tesla számítása szerint körülbelül kétszeres a különbség. Saját számításainkba nem foglaltuk bele az adókat, mivel azokról jelenleg még nincsenek határozatok. A kisebb eltérések az egyes országok által, az útdíj meghatározására szolgáló különböző szoftverekből adódhatnak. Emellett valószínüsíthető, hogy a jövőben útdíj kedvezményt fognak adni az elektromos kamionokra.

3. táblázat Teljes költség éves bontásban

\begin{tabular}{|c|l|c|c|c|c|c|c|}
\hline \multicolumn{2}{|c|}{ Teljes költség évenkénti bontásban (millió Ft) } & 0. év (Vétel) & 1. év & 2. év & 3. év & 4. év & 5. év \\
\hline \multirow{2}{*}{ Tesla szerint } & Elektromos kamion (Tesla Semi) & 53,00 & 86,90 & 120,80 & 154,70 & 188,60 & 222,50 \\
\cline { 2 - 9 } & Átlagos Dízel kamion & 30,00 & 70,80 & 111,60 & 152,40 & 193,20 & 234,00 \\
\hline \multirow{2}{*}{ Saját számítás } & Elektromos kamion (Tesla Semi) & 53,00 & 71,39 & 89,78 & 108,17 & 126,56 & 144,95 \\
\cline { 2 - 8 } & Átlagos Dízel kamion & 30,00 & 61,33 & 92,66 & 123,99 & 155,32 & 186,65 \\
\hline
\end{tabular}

A számítások végeredményét a 3. táblázat és grafikon formájában pedig az 1. ábra szemlélteti, melyek egyértelmủen alátámasztják az elektromos kamionban rejlő versenyelőnyöket. 
Megállapíthatjuk, hogy az elektromos kamionokban rejlik a jövő, az olcsóbb ráfordítási költségeknek, valamint a zéró emissziónak köszönhetően.

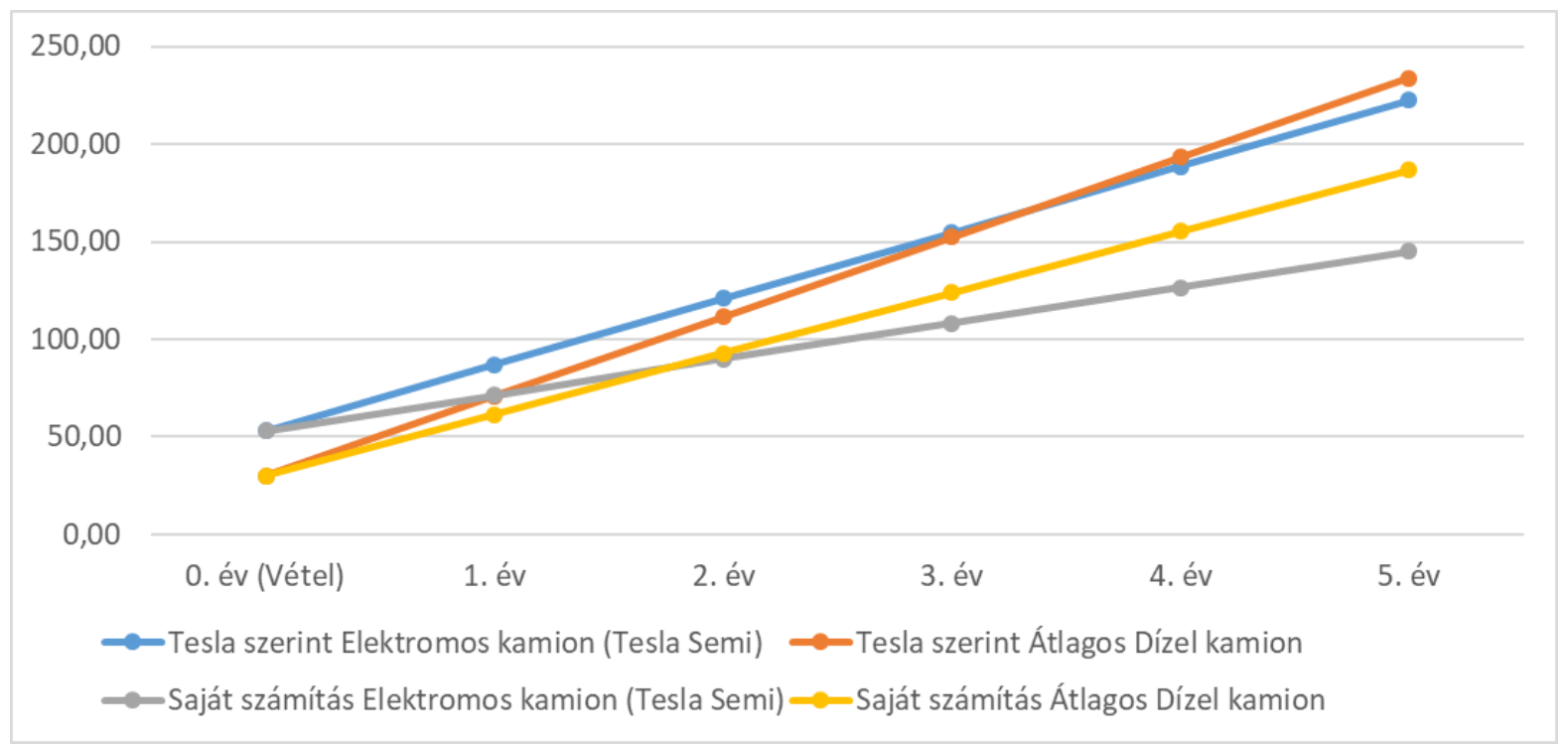

\section{1. ábra Teljes költség éves bontásban}

A diagramon is látható, hogy a számítások alapján körülbelül 2 év után fog megtérülni ez a befektetés a fuvarozási vállalatnak. A Tesla becslései ennél kicsit pesszimistábbak, az ő számításaik alapján a 3. év után várható a megtérülés.

Az tehát egyértelmüen kirajzolódik, hogy az elektromos anyagmozgatásnak jövője van az iparban. Hiába a magas árak, egy nagyobb multinacionális cég, mely megengedhet magának drágább vontatókat, hosszú távú befektetés céljából idővel elkezdi lecserélni kamionjait. Ezt támasztja alá az is, hogy a Tesla modellje még meg sem jelent a piacon, de már több ezer darabos elörendelést adtak le különböző vállalatok.

\section{5. Összefoglalás}

Jelen kutatómunka keretében megvizsgáltunk és elemeztünk több elektromos autót, valamint egy elektromos targoncát is abból a célból, hogy átfogóbb képet kapjunk az elektromos jármüvekröl és ezek alapján felmérjük az elektromos tehergépjármüvek jövőjét. Számításainkból kiderül, hogy az elektromos jármüvek a magasabb beszerzési ár mellett is viszonylag rövidebb idő alatt megtérülnek, mint a belsőégésü hajtással ellátott verzióik. Ezt az állítást támasztják alá a Tesla számításai is; szerintük 1 millió megtett mérföld után körülbelül 200.000 \$ megtakarítás érhető el, amely árfolyam függvényében 50-60 millió forint körül várható.

A táblázatokból, illetve az összehasonlító elemzésekből is kiderül, hogy a legnagyobb különbség az első időszakban a vontató ára, azonban a jelentős üzemanyag/energia költség különbségnek köszönhetően 2-3 éven belül ez megtérül, és megtakarítást érhet el bármelyik vállalat a befektetése után. 
Véleményünk szerint összességében ez a technológia idővel egy járható út lesz. Azonban azzal is kalkulálni kell, hogy a technológia még nagyon gyerekcipőben jár, így mint minden más új termék vagy innováció rendelkezhet olyan problémákkal, melyek a tesztüzem során nem jelentkeztek. Ennek a lehetőségét az első vásárlóknak bele kell kalkulálni.

Az elektromos jármüvek az elkövetkezendő évtizedek során egyre nagyobb teret fognak hódítani, ezáltal reményeink szerint több problémára is megoldást nyújtanak majd. Ilyenek lehetnek az akkumulátor problémák, a nem megújuló energiaforrásokról való áttérés a megújulókra, valamint az egyre nagyobb gondot jelentő környezetszennyezés. Fontos megjegyezni, hogy hiába az elektromos meghajtás, ha az áramot nem megfelelő módon állítják elö, így fontos lenne, hogy olyan technológiák is még nagyobb teret hódítsanak, melyekkel környezetkímélő módon lehet nagy mennyiségü energiát elóállítani.

\section{Köszönetnyilvánítás}

A cikkben ismertetett kutatómunka az EFOP-3.6.1-16-2016-00011 jelü „Fiatalodó és Megújuló Egyetem - Innovatív Tudásváros - a Miskolci Egyetem intelligens szakosodást szolgáló intézményi fejlesztése" projekt részeként - a Széchenyi 2020 keretében - az Európai Unió támogatásával, az Európai Szociális Alap társfinanszírozásával valósul meg.

\section{Irodalomjegyzék}

[1] Thomas Parker, the inventor. Forrás: https://en.wikipedia.org/wiki/Thomas_Parker_(inventor). Letöltve: 2019.07.12.

[2] Tamás, P., Illés, B., Dobos, P., Skapinyecz, R.: New Challenges for Quality Assurance of Manufacturing Processes in Industry 4.0, Solid State Phenomena 2017, 261, pp. 481-486. https://doi.org/10.4028/www.scientific.net/SSP.261.481

[3] Dobos, P., Illés, B., Tamás, P.: Conception for selection of adequate warehouse material handling strategy, Advanced Logistic Systems: Theory and Practice 2015, 9 No.1, pp. 53-60.

[4] Bányai T.: Direct shipment vs. cross docking, Advanced Logistic Systems: Theory and Practice 2012, 6 No.1, pp. 83-88.

[5] Simon, Zs. Új európai uniós célkitüzés nyithat utat a villanykamionoknak. Forrás: https://villanyautosok.hu/2018/05/18/uj-europai-unios-celkituzes-nyithat-utat-avillanykamionoknak/. Letöltve: 2019.07.12.

[6] Simon, Zs. Kétkedők újabb hullámával néznek szembe az elektromos kamionok. Forrás: https://villanyautosok.hu/2018/08/28/ketkedok-ujabb-hullamaval-neznek-szembe-azelektromos-kamionok/. Letöltve: 2019.07.12.

[7] Simon, Zs. $1000 \mathrm{kWh}-\mathrm{s}$ villanykamiont jelentett be a Nikola Motors. Forrás: https://villanyautosok.hu/2019/02/11/1000-kwh-s-villanykamiont-jelentett-be-a-nikolamotors/. Letöltve: 2019.07.12.

[8] Tesla Semi. Forrás: https://en.wikipedia.org/wiki/Tesla_Semi. Letöltve: 2019.07.12.

[9] McFadden, C. Diesel Engine vs. EV: Which is better? Forrás: https://interestingengineering.com/diesel-engine-vs-ev-which-is-better. Letöltve: 2019.07.12. 